\title{
MODIFIKASI DAN UJI KINERJA MESIN PEMARUT SAGU TIPE SILINDER
}

\section{MODIFICATION AND PERFORMANCE TEST OF CYLINDER-TYPE SAGO GRATING MACHINE}

\author{
Ahmad Thoriq ${ }^{1 \bowtie}$ dan Agus Sutejo ${ }^{2}$ \\ ${ }^{1}$ Departemen Teknik Pertanian dan Biosistem, FTIP, Universitas Padjadjaran \\ ${ }^{2}$ Departemen Teknik Mesin dan Biosistem, Fateta, Institut Pertanian Bogor \\ \Komunikasi Penulis,Email : thoriq@unpad.ac.id \\ DOI: http://dx.doi.org/10.23960/jtep-lv7i1.35-40
}

Naskah ini diterima pada 20 Februari 2018; revisi pada 11 Maret 2018;

disetujui untuk dipublikasikan pada 26 April 2018

\begin{abstract}
In previous research it was revealed that users of TPB 01 sago grating type machine in Papua complained about the difficulty of tightening the v-belt, the presence of scarring contact with the foundation on the sago input section and the many parts of the sago stalk which is not completely dissolved. This study aims to improve the performance of sago grating type TPB 01 engine through the modification of some parts of the machine. The method used in this research is through engineering design approach which consists of problem identification, formulation of modification concept, engineering drawing, functional test and performance test. Based on the problem identification, the modified part of the engine is to move the driving force into the holder located on the side of the engine and add a $5 \mathrm{~mm}$ nylon slab on the entry base. The scar will contact nylon but due to the technical characteristics of the softer nylon compared to the scar causing the nylon to erode and form the groove of the scar. The result of the modified machine test showed that there was no unsolved sago tree where there was previously unsolved sago stalk of $4.56 \%$. Besides, the solubility efficiency increased by $2.28 \%$ compared to the previous one.
\end{abstract}

Keywords: machine modification; grated machine; grate cylinder; sago machine

\begin{abstract}
ABSTRAK
Pada penelitian yang telah dilakukan sebelumnya terungkap bahwa pengguna mesin pemarut sagu tipe TPB 01 di Papua mengeluhkan beberapa kesulitan yaitu mengencangkan sabuk v-belt, adanya kontak mata parut dengan landasan pada bagian pemasukan batang sagu dan banyaknya bagian batang sagu yang tidak terparut sempurna. Penelitian ini bertujuan untuk memperbaiki kinerja mesin pemarut sagu tipe TPB 01 melalui modifikasi beberapa bagian mesin. Metode yang digunakan pada penelitian ini yaitu melalui pendekatan rancangan teknik yang terdiri atas indentifikasi masalah, perumusan konsep desain modofikasi alat, uji fungsional dan uji kinerja. Berdasarkan identifikasi masalah, bagian mesin yang dimodifikasi adalah memindahkan tenaga penggerak ke dudukan yang terletak di bagian samping mesin dan menambahkan lempengan nilon $5 \mathrm{~mm}$ pada landasan bagian pemasukan. Mata parut akan kontak dengan nilon namun karena karakteristik teknik dari nilon yang lebih lunak dibandingkan dengan mata parut menyebabkan nilon terkikis dan membentuk alur mata parut. Hasil pengujian mesin hasil modifikasi menunjukkan tidak terdapat batang sagu yang tidak terparut dimana sebelumnya terdapat batang sagu yang tidak terparut sebesar $4,56 \%$ selain itu efisiensi pemarutan meningkat sebesar 2,28 \% dibandingkan sebelumnya.
\end{abstract}

Kata kunci : modifikasi mesin; mesin pemarut; silinder parut; mesin sagu

\section{PENDAHULUAN}

Produk utama dari tanaman sagu adalah pati yang dapat dimanfaatkan untuk berbagai macam industri seperti industri makanan, industri minuman, industri kimia, industri kemasan, dan bioenergi. Sedangkan limbah sagu berupa kulit kayu dijadikan sebagai bahan bakar dan ampas sagu dapat dijadikan sebagai briket, media tanam sayuran dan tanaman perkebunan, media tanam jamur, absorban, herbisida nabati, nitroselulosa pakan ternak dan papan partikel komposit. 
Saat ini indonesia tercatat memiliki tiga industri pengolahan sagu skala besar dengan menggunakan mesin pengolahan modern yang terletak di Kepulauan Riau dan Papua Barat. Sedangkan industri pengolahan sagu skala kecil dan menengah berkembang diwilayah Banten dan Kepulauan Riau. Padahal 95\% tanaman sagu tumbuh di wilayah Provinsi Papua dan Papua Barat (Bintoro, 2013). Luas potensi tanaman sagu di Papua dan Pupua Barat diperkirakan mencapai 3.173.322 ha (UP4B, 2013).

Industri pengolahan sagu skala besar menggunakan teknologi proses dan mesin dari luar Negeri sehingga fokus kegiatan yang dilakukan lebih kepada perawatan dan modifikasi mesin untuk meningkatkan produktivitas dan efesiensi produksi. Pengembangan mesin masih sangat dibutuhkan pada industri pengolahan sagu skala kecil dan menengah, karena penggunaan alat dan mesin telah terbukti dapat meningkatkan produktivitas, efisiensi dan kualitas produk yang dihasilkan. Namun untuk menerapkan alat dan mesin pengolahan sagu di Pulau Papua kiranya perlu dilakukan secara bertahap dengan memberikan contoh nyata dan tentunya tanpa menggubah kebiasaan yang telah dilakukan oleh petani sagu di Papua. Kebanyakan peneliti, pemerintah pusat atau pengusaha berpikir apa yang bisa mereka kerjakan namun hanya sedikit sekali yang berpikir apa yang orang papua bisa kerjakan (Thoriq dan Herodian, 2015).

Penerapan alat dan mesin pengolahan sagu di Pulau Papua hanya sebatas pada penggunaan mesin pemarut terutama di lokasi sagu yang lebih dekat dengan kota sementara lokasi sagu yang jauh dengan kota (pedalaman) pengecilan ukuran sagu masih dilakukan menggunakan peralatan sederhana yang terbuat dari pipa besi dengan gagang kayu atau disebut dengan pangkur. Adapun proses setelah pemarutan masih dilakukan secara manual (Thoriq dan Herodian, 2015).

Kelompok masyarakat yang tinggal dekat dengan pusat Kota berinovasi dengan membuat mesin pemarut namun mesin parut yang dibuat masih belum memperhatikan faktor keamanan pangan diantaranya bagian yang kontak dengan sagu pada mesin pemarut tersebut terbuat dari besi yang mudah berkarat (Thoriq dan Herodian, 2015). Beberapa peneliti telah berhasil menciptakan mesin pemarut sagu diantaranya Indra dan Sutanto (2016) merancang alat pemarut sagu portable dengan kapasitas pemarutan mencapai $318,62 \mathrm{~kg} / \mathrm{jam}$. Alat tersebut berbentuk seperti gerobak dan proses pemindahan dilakukan menggunakan kendaraan bermotor. Namun alat tersebut hanya cocok diterapkan pada daerah dengan akses kondisi jalan yang baik. Reniana dkk (2017) membuat prototype mesin pemarut sagu dengan kapasitas pemarutan mencapai $322,52 \mathrm{~kg} / \mathrm{jam}$. Namun perlu dilakukan pembenahan mengenai bagian fungsional (silinder parut) yang ditujukan untuk meningkatkan kinerjanya serta perlu dilakukan analisis ekonomi untuk melihat tingkat kelayakan.

Dengan melihat mesin pemarut hasil desain yang terdapat di Provinsi Papua, bengkel mesin industri di Bogor mendesain mesin parut sesuai dengan karakter masyarakat Papua. Mesin tersebut memiliki kapsaitas $649,38 \mathrm{~kg} / \mathrm{jam}$. Mesin parut tersebut telah dikirim sebanyak 28 unit dan dipergunakan masyarakat Papua khususnya Kabupaten Teluk Bintuni Papua Barat (Thoriq dan Sampurno, 2016). Namun masih terdapat beberapa perbaikan untuk meningkatkan kinerja mesin diantaranya pemindahan posisi motor penggerak sehingga memudahkan pengencangan v-belt, dan modifikasi desain hopper sehingga tidak terdapat bagian batang sagu yang tidak terparut sempurna (Thoriq dan Sutejo, 2017). Penelitian ini bertujuan untuk memperbaiki kinerja mesin pemarut sagu tipe TPB 01 melalui modifikasi beberapa bagian mesin.

\section{BAHAN DAN METODE}

Bahan yang digunakan untuk pembuatan konstruksi mesin terdiri atas Poros as p $30 \mathrm{~mm}$, $65 \mathrm{~cm}$, Silinder p $17 \mathrm{~mm}, 40 \mathrm{~cm}$, Kawat las SS 304, Plat SS 304, tebal $2 \mathrm{~mm}$, Hollow SS, $4 \times 4 \mathrm{~cm}$, Sabuk V tipe B65, Puli p $15 \mathrm{~cm}$, Puli p $7.2 \mathrm{~cm}$, Motor bensin (5,5 HP), Mur dan baut SS, Bearing UCP 207, Batu gurinda dan lembaran nilon $5 \mathrm{~mm}$. Peralatan yang digunakan untuk pembuatan kontruksi mesin terdiri atas Las argon, Gurinda tangan, Mesin bubut, mesin bor, Meteran, Kunci - kunci, Pemotong plat dan bahan dan peralatan 
yang digunakan untuk pengujian mesin terdiri atas Bongkahan batang sagu, Stop watch, Tachometer, Timbangan digital, bak penampung hasil parutan, dan, ATK.

Metode yang digunakan pada penelitian ini yaitu melalui pendekatan rancangan teknik :

\subsection{Indentifikasi Masalah}

Berdasarkan penelitian sebelumnya pengguna mengeluhkan kesulitan mengencangkan sabuk v-belt yang menghubungkan antara puli poros silinder parut dan puli motor penggerak hal ini disebabkan oleh posisi motor penggerak terletak tapat di bagian bawah silinder parut sehingga sulit untuk digeser karena ruang yang terbatas. Selain itu pengguna mengeluhkan adanya kontak mata parut dengan landasan pada bagian pemasukan batang sagu dan banyaknya bagian batang sagu yang tidak terparut sempurna.

\subsection{Perumusan Konsep Modifikasi}

Modifikasi dilakukan dengan memindahkan mesin dari bagian bawah silinder parut ke bagian samping dengan membuat rangka tambahan sehingga mesin dapat digeser untuk pengencangan v-belt. Untuk menghilangkan bagian dari batang sagu yang tidak terparut, landasan pada bagian pemasukan ditambahkan nilon dengan ketebalan $5 \mathrm{~mm}$. Mata parut akan kontak dengan nilon namun karena karakteristik teknik dari nilon yang lebih lunak dibandingkan dengan mata parut menyebabkan nilon terkikis dan membentuk alur mata parut.

\subsection{Desain dan Pembuatan Mesin}

Desain digunakan sebagai dasar pembuatan komponen pada proses manufaktur mesin pamarut Setiap komponen dibuat dan dirangkai menjadi satu kesatuan.

\subsection{Uji Fungsional}

Uji fungsional dilakukan untuk mengetahui apakah setiap bagian alat dapat berfungsi dengan baik atau tidak. Pengujian ini dilakukan setelah alat pemarut sagu telah selesai proses pembuatannya. Bila semua komponen berfungsi dengan baik dan bekerja sesuai dengan yang diharapkan maka selanjutnya dilakukan uji kinerja sedangkan bila terdapat komponen yang bekerja tidak sesuai dengan yang diharapkan maka dilakukan modifikasi.

\subsection{Uji Kinerja}

Untuk memastikan mesin pemarut sagu bekerja sesuai dengan tujuan dan kriteria yang ingin dicapai maka uji kinerja dilakukan sebanyak tiga kali ulangan. Bahan yang digunakan pada uji kinerja ini adalah bongkahan batang sagu. Pemotongan batang sagu menjadi bongkahan bertujuan untuk mempermudah proses masuk kebagian silinder parut. Sebelum diparut bongkahan batang sagu tersebut ditimbang menggunakan timbangan digital. Setelah diparut empulur sagu hasil parutan serta batang sagu yang tidak terparut dimasukkan ke dalam kantong plastik, diberi label kode dan ditimbang sesuai dengan urutan pemarutan. Beberapa parameter yang diukur selama proses pengujian terdiri atas :

\subsubsection{Kapasitas efektif}

Kapasitas efektif dihitung dengan cara mencatat lansung hasil parutan dalam selang waktu tertentu. Jika kapasitas efektif dilambangkan dengan $\mathrm{C}_{\mathrm{e}}$ dan sagu hasil parutan adalah $\mathrm{S}_{\mathrm{p}}$ dalam selang waktu $(\mathrm{t})$ maka kapasitas efektif pemarutan adalah :

$$
C_{\theta}=S_{p} / t
$$

Dimana :

$\mathrm{C}_{\mathrm{e}}=$ kapasitas efektif $(\mathrm{kg} / \mathrm{jam})$

$\mathrm{S}_{\mathrm{p}}=$ empulur sagu hasil parutan $(\mathrm{kg})$

$\mathrm{t}=$ Waktu pemarutan (Jam)

\subsubsection{Kehilangan hasil parutan}

Kehilangan hasil parutan dapat diketahui dengan cara menghitung berat sagu sebelum diparut dengan hasil parutan. Jika berat sagu sebelum diparut adalah $\mathrm{B}_{\mathrm{a}}$ empulur sagu hasil parutan $\left(\mathrm{S}_{\mathrm{p}}\right)$ maka kehilangan hasil pemarutan $\left(\mathrm{K}_{\mathrm{p}}\right)$ dapat dirumuskan :

$$
K_{p}=\frac{B_{a}-s_{p}}{B_{a}} \times 100 \%
$$

Dimana :

$\mathrm{Kp}=$ kehilangan hasil parutan (\%)

$\mathrm{Ba}=$ berat awal bongkahan batang sagu $(\mathrm{kg})$

\subsubsection{Efisiensi pemarutan}

Efisiensi pemarutan diperoleh dengan cara membandingkan sagu hasil parutan $\left(\mathrm{S}_{\mathrm{p}}\right)$ dengan empulur batang sagu yang akan diparut $\left(B_{a}\right)$ seperti pada persamaan 3 . 


$$
E_{f}=\frac{s_{p}}{B_{a}} \times 100 \%
$$

Dimana :

$\mathrm{Ef}=$ Efisiensi pemarutan $(\%)$

\section{HASIL DAN PEMBAHASAN}

\subsection{Modifikasi Konstruksi Mesin Pemarut Sagu}

Konstruksi mesin pemarut sagu hasil penelitian ini sama dengan konstruksi mesin pemarut sagu hasil penelitian sebelumnya yang terdiri atas tenaga penggerak berupa motor bensin 5,5 HP dengan sistem transmisi belt dan pulley dengan perbandingan diameter $1: 2$, V-bel yang digunakan adalah tipe B65. Konstruksi penutup silinder parut dan bagian pengeluaran serta bagian pemasukan terbuat dari plat stainless steel 304 (SS 304) dengan ketebalan 2 mm, rangka mesin terbuat dari hollow SS $4 \times 4 \mathrm{~cm}$, mata parut terbuat dari kawat SS $\varnothing 3 \mathrm{~mm}$ dan panjang $15 \mathrm{~mm}$ (Thoriq dan Sutejo, 2017). Perbedaannya hasil modifikasi terdapat pada posisi motor pengerak, dimana sebelumnya terletak tepat dibawah silinder parut dipindah ke bagian samping sebagaimana dapat dilihat pada Gambar 1.

Beberapa desain mesin pemarut sagu meletakkan tenaga pengerak tepat dibawah silinder parut (Irawan 2009; Kurniawan dkk 2012 ; Santoso dkk 2015; Reniana dkk 2017). Hal ini bertujuan agar mesin terlihat compact, namun menurut pengguna bila tenaga penggerak yang digunakan adalah motor bensin maka terdapat kesulitan pada proses pengencangan sabuk $v$-belt yang menghubungkan antara puli poros silinder parut dan puli motor penggerak. Karena posisi motor penggerak terletak tapat di bagian bawah silinder parut sehingga sulit untuk digeser akibat ruang yang terbatas (Thoriq dan Sutejo, 2017). Berdasarkan masukkan tersebut motor bensin diletakkan pada dudukan tepat dibagian samping dari konstruksi mesin.

Permasalahan lainnya adalah adanya kontak antara mata parut dengan landasan pada bagian pemasukkan yang menghasilkan bunyi (Thoriq dan Sutejo, 2017). Hal ini karena kontak yang terjadi antara jenis bahan dengan kekerasan yang sama dimana mata parut terbuat dari kawat stainless steel $\emptyset 3 \mathrm{~mm}$ dan landasan landasan pada bagian pemasukan terbuat dari plat stainless steel $2 \mathrm{~mm}$. Bila berlangsung dalam jangka waktu lama maka mata parut terkikis bahkan mengalami kerusakan. Jarak antara mata parut dan landasan pada bagian pemasukan harus diatur serapat mungkin hal ini bertujuan untuk meminimalisasi banyaknya empulur sagu yang tidak terparut.

Modifikasi dilakukan dengan mengganti landasan pada bagian pemasukan menggunakan bahan yang lebih lunak. sehingga bila terjadi kontak dengan mata parut maka landasan pada bagian pemasukkan akan terkikis dan membentuk alus mata parut. Berdasarkan analisis bahan teknik maka bahan yang dipilih adalah nilon dengan ketebalan $5 \mathrm{~mm}$ yang dipasangkan pada bagian pemasukan (Gambar 2).

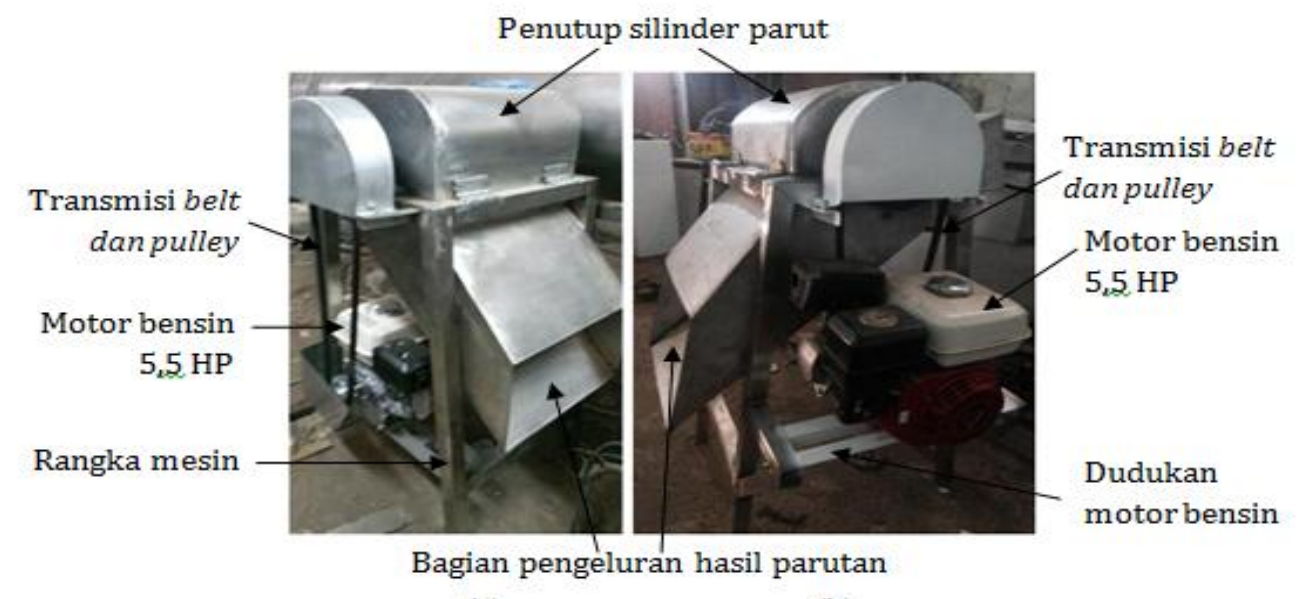

(a)

(b)

Gambar 1. Mesin pemarut sagu, (a) sebelum modifikasi, (b) sesudah modifikasi 


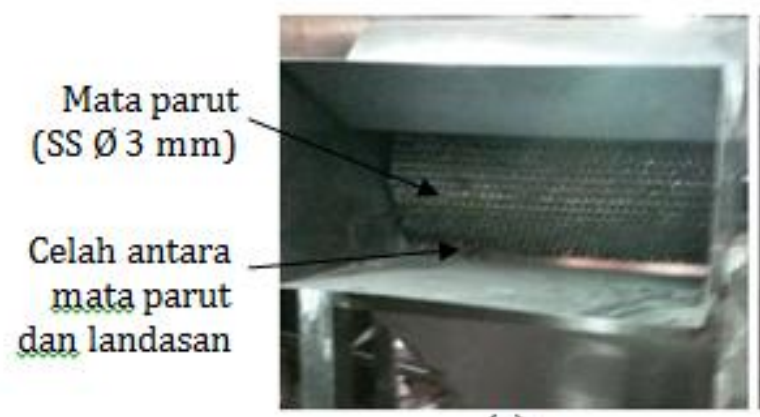

(a)

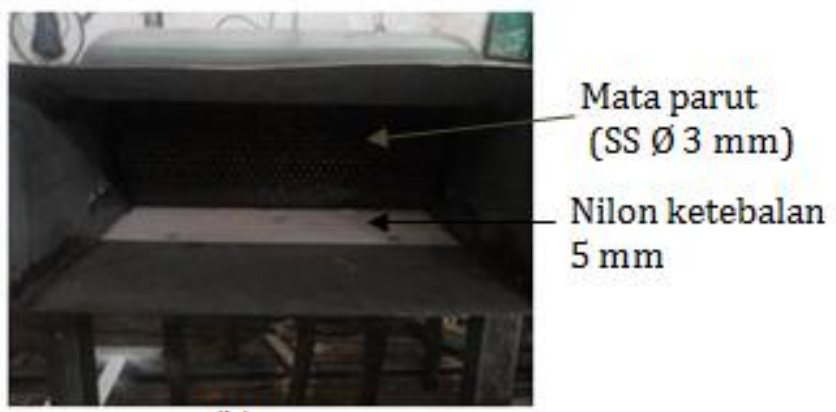

(b)

Gambar 2. Landasan pada bagian pemasukan mesin pemarut sagu (a) sebelum modifikasi, (b) setelah modifikasi

Berdasarkan Gambar 2 terlihat bahwa pada bagian pemasukan sebelum modifikasi terdapat celah antara mata parut dengan landasan. Bila landasan dan mata parut dirapatkan maka akan terjadi kontak dan menghasilkan bunyi. Sedangkan pada bagian pemasukan yang telah dimodifikasi tidak terdapat celah. Hal ini akan meminimalisir empulur sagu yang tidak terparut. Kontak yang terjadi antara landasan nilon dengan mata parut hanya terjadi pada beberapa putaran silinder parut selanjutnya akan terbentuk alur mata parut pada landasan nilon.

\subsection{Uji Kinerja Mesin Pemarut Sagu}

Uji kinerja dilakukan untuk mengetahui apakah mesin yang dibuat telah memenuhi tujuan dan kriteria yang ingin dicapai atau tidak. Uji kinerja mesin pemarut sagu dillakukan pada putaran silinder parut sebesar 1400 RPM. Beberapaparameter yang diukur pada pengujian kinerja meliputi:

\subsubsection{Kapasitas mesin}

Berdasarkan pengujian yang dilakukan, rata-rata kapasitas efektif mesin pemarut sagu hasil modifikasi adalah sebesar $571,15 \mathrm{~kg} / \mathrm{jam}$. Kapasitas tersebut lebih kecil dibandingkan dengan pengujian mesin sebelum modifikasi yaitu sebesar 649,38 kg/jam (Thoriq dan Sutejo, 2017). Namun lebih baik jika dibandingkan dengan mesin pemarut sagu hasil penelitian Reniana dkk (2017). Faktor utama yang mempengaruhi menurunnya kapasitas pemarutan adalah putaran silinder parut, pada putaran rendah akan menghasilkan kapasitas pemarutan yang rendah namun pada putaran silinder parut yang tinggi akan menghasilkan getaran yang tinggi dan kapasitas pemarutan yang rendah karena banyaknya empulur hasil parutan yang hilang (Thoriq dan Sutejo, 2017). Faktor lain yang juga diduga mempengaruhi kapasitas pemarutan mesin pemarut sagu adalah pengalaman operator, desain dan dimensi silinder parut.

\subsubsection{Kehilangan hasil parutan}

Kehilangan hasil parutan sagu berupa kehilangan sementara dan kehilangan permanen. Kehilangan sementara adalah hasil parutan sagu yang tertinggal pada bagian mesin dan sebagian besar menempel pada penutup silinder. Hasil parutan tersebut dapat diambil setelah proses pemarutan selesai. Sedangkan kehilangan permanen berupa batang sagu yang tidak terparut yang berbentuk lempengan dan berukuran lebar / panjang berkisar antara $5-15 \mathrm{~cm}$ dengan tebal $5 \mathrm{~mm}$.

Berdasarkan hasil pengujian, rata-rata kehilangan hasil parutan yang tertinggal pada penutup selinder adalah sebesar $4,68 \%$ dan tidak terdapat batang sagu yang tidak terparut. Pada mesin sebelum modifikasi kehilangan hasil parutan yaitu sebesar $6,71 \%$ berasal dari batang sagu yang tidak terparut sebesar $4,56 \%$ dan empulur sagu hasil parutan yang tertinggal pada penutup silinder sebesar 2,39\% (Thoriq dan Sutejo, 2017).

\subsubsection{Efisiensi pemarutan}

Berdasarkan hasil pengujian, mesin hasil modifikasi memiliki efesiensi pemarutan lebih tinggi yaitu sebesar 95,32 \% dibandingkan dengan sebelum modifikasi yaitu sebesar 93,04 $\%$ dan lebih baik dibandingkan dengan efesiensi pemarutan dengan mata parut yang sama hasil penelitian Payung (2007) yaitu sebesar 90,83 
$\%$ sedangkan efesiensi pemarutan pada mata parut berbentuk jarum yaitu sebesar 95,78 \% (Irawan, 2009). Faktor utama yang menyebabkan meningkatnya efesiensi mesin dipengaruhi oleh modifikasi dengan pemasangan nilon $5 \mathrm{~mm}$ pada landasan bagian pemasukan yang menyebabkan bongkahan sagu terparut sempurna.

\section{KESIMPULAN}

Mesin pemarut sagu hasil modifikasi memiliki dimensi tinggi $120 \mathrm{~cm}$, lebar $60 \mathrm{~cm}$ dan panjang $65 \mathrm{~cm}$. Menggunakan tenaga penggerak motor bensin 5,5 HP yang diletakkan pada bagian samping mesin dengan sistem transmisi belt dan pulley. Dipasangkan nilon dengan tebal $5 \mathrm{~mm}$ pada landasan bagian pemasukan dan seluruh konstruksi mesin terbuat dari stainless steel. Hasil uji kinerja mesin hasil modifikasi terdapat hasil parutan yang menempel pada penutup silinder mesin sebesar $4,68 \%$ dan tidak terdapat batang sagu yang tidak terparut dimana sebelumnya terdapat batang sagu yang tidak terparut sebesar $4,56 \%$ selain itu efisiensi pemarutan meningkat sebesar 2,28 \% dibandingkan sebelumnya.

\section{UCAPAN TERIMA KASIH}

Ucapan terima kasih diberikan kepada Dinas Pertanian Kabupaten Teluk Bintuni, Provinsi Papua Barat yang telah memberikan kepercayaan kepada penulis untuk membantu masyarakat Papua melaui penelitian dan pengembangan mesin pemarut sagu.

\section{DAFTAR PUSTAKA}

Bintoro, MH. 2008. Bercocok Tanam Sagu. IPB Press, Bogor.

Irawan, P. 2009. Rancangan dan Uji Teknis Alat PemarutSagu Tipe Silinder. Skripsi. Fakultas Teknologi Pertanian. Institut Pertanian Bogor, Bogor.

Indra A. dan Sutanto A. 2016. Alat pemarut batang sagu portable. Jurnal Inovtek 6 (2) : 73-77
Kurniawan, A., Darma, Istalaksana, P. 2012. Pengembangan agroindustri pengolahan sagu di Provinsi Papua untuk mendukung ketahanan dan disversifikasi pangan. Prosiding Seminar Insentif Riset Sistem Inovasi Nasional . 29 - 30 November 2012. Bandung. Hal. 214 - 216.

Payung, P. (2007). Rancang Bangun dan Uji Kinerja Alat Penghancur Mekanis Empulur Sagu (Metroxylon sp.) Tipe Piringan Datar. Tesis. Fakultas Teknologi Pertanian. Universitas Gadjah Mada, Yogyakarta.

Reniana, Darma dan Kurniawan A. 2017. Prototipe mesin parut empulur sagu tipe silinder bertenaga motor bakar. Jurnal Teknik Pertanian Lampung 6 (2) : 89-94.

Santoso, Mislaini R., Putra R. 2015. Rancang bangun alat pencacah dan pemarut sagu dengan sumber pengerak motor listrik. Prosiding Seminar Agroindustri dan Lokakarya Nasional FKPT - TPI. 2 -3 September 2015.Madura. Hal : C13 - C32.

Thoriq, A. dan Herodian, S. 2015. Perkembangan alat dan mesin pengolahan sagu di pulau papua dan strategi pengembangannya. Prosiding Seminar Nasianal Informatika Pertanian. 12-13 November 2015. Bandung. Hal. 70 - 83.

Thoriq, A. dan Sampurno, R.M. 2016. Analisis tekno ekonomi aplikasi mesin pemarut sagu di Kabupaten Teluk Bintuni, Papua Barat. Jurnal Teknologi Pertanain 17 (2) : 129-137.

Thoriq, A. dan Sutejo, A. 2017. Desain dan uji kinerja mesin pemarut sagu tipe TPB 01. Jurnal Agritech 37 (3) : 453-461. Doi : 10.22146/agritech.12789.

[UP4B] Unit Percepatan Pembangunan Provinsi Papua dan Provinsi Papua Barat. 2013. Master Plan Pengembangan Sagu Sebagai Komoditas Unggulan Provinsi Papua dan Provinsi Papua Barat. Laporan Kajian. UP4B. Jakarta. 